\title{
住民主体による廃校から高齢者施設への転用に関寸る事例的考察
}

\section{A CASE STUDY ON THE PROCESS OF CONVERSION FROM ABOLISHED SCHOOL TO INSTITUTION FOR THE ELDERLY THROUGH THE ACTION BY RESIDENTS}

\author{
鈴木 健二*, 友清 貴 和** \\ Kenji SUZUKI and Takakazu TOMOKIYO
}

\begin{abstract}
The purpose of this study is to clarify the significances of independent action by residents in the process of conversion to day care center for the elderly. For this objective, NPO which was established in a solitary island by residents were surveyed by means of interview. Some results show as follows:

1) Calculating the number of institutions for the elderly, the number per area in solitary islands is smaller than that in the whole of Japan.

2) Dividing the action by residents into four stages, transition of the conversion process were shown.

3) Newly redesigned day care center near to the community plays important role to improve the quality of life of the elderly and their family.
\end{abstract}

Keywords : independent action by residents, the aged living at their homes, conversion,solitary island, aging in places 住民主体、在宅高齢者、転用、離島、在宅生活の継続

\section{1. 研究の背景}

高㱓化が著しく進行する我が国においては、介護保険の開始以降、 全国各地で様々な高秢者施設の整備が進められている。高龄者数が多 い事から民間も参入して施設整備が行われている都市部とは反対に、 多くの問題を抱えているのが離島・過疎地域である。特に離島地域で は民間の参入を期待する事が難しく、財政的な事情等から公主導の 施設整備も困難になりつつあることから、施設整備は進んでいると は言い難いのが現状である。従って施設整備が進んでいない離島で は、要介護の状態になった時には暮らし慣れた住まいと地域を離れ、 島外の施設へ入居せざるを得ないケースも見られる 注1 等、高秢者居住 の問題は依然として厳しい状況に置かれており、こうした現状を打 開していくための手法や知見の蓄積が強く求められている。

\section{2. 研究の位置づけと目的}

従来、我が国では国や自治体等の「公」を中心に多くの施設整備が 進められてきたが、昨今では、各地域や住民の創意工夫による「共」 の取り組みが注目を集めつつあり、構造改革特区の実施 (2002 年 9 月) や地域再生本部の発足 (2003 年 10 月) 等、地域の自立に向けた 活動を見出そうとする動きが社会的にも定着しつつある主2。特に福 祉の分野においては、ボランティアやNPO による活動を媒介とした

\section{参加型福祉社会の構築が䓵われている。}

こうした地域や住民による「共」の取組みに関する既往の研究とし ては、住民参加・住民主体」をキーワードとして主にまちづくりに関 するもの ${ }^{\text {注 } 3}$ や、集合住宅や住環境を対象としたもの ${ }^{\text {注 } 4}$ が数多くなさ れており、特にその過程において住民を交えたワークショップという 手法を用いる事の有効性について多くの検証がなされている。また、 本研究のように高路者施設を対象とした既往の研究としては、浜崎 らによるもの注 5 があり、活動の経緯についての報告がなされている が、これらの多くは、建築等の専門家や行政の支援が介在すること で可能となった非常に恵まれた事例が対象となっていると思われる。

これに対して本研究では、廃校を転用することで高歯者施設の整 備が行われた離島での事例を対象としているが、その特徴としては、 (1)専門家の参画や行政の支援が殆ど介在せず、地域住民が中心となっ て施設整備に至る活動が行われている点、(2)転用の計画段階だけでな く、施工の段階までも含めて地域住民が中心になって活動が行わ机て いる点、(3)高路化が進行している離島地域の事例で、公的資金の援助 が無い等、地理的にも予算的にも非常に撖しい条件の下でありながら も実現に結びつけている点の 3 点が挙げられる。そこで本研究では、 まず離島地域のデー夕を全国平均のものと比較し、離島地域を取り巻 く現状について整理する。次に、非常に困難な状況に置かれながらも、

※本論文は，2005年度日本建築学会学術講演梗概集の発表論文(文献 1・2)に加筆・修正を加えたものである。

$*$ 鹿児島大学工学部建築学科 助手・博士 (工学 $)$ Research Assoc., Faculty of Engineering, Kagoshima University, Dr. Eng.

** 鹿児島大学工学部建築学科 教授. 工博 Research Assoc., Faculty of Engineering, Kagoshima Universi
Prof., Faculty of Engineering, Kagoshima University, Dr. Eng. 


\section{表 1 NPO 屋久島の概要}

設 立：2003 年 12 月

会員数：正会員 22 名、準会員 64 名で発足

目 的：高齢者・障害者が住み慣れた場所で生活できるための 介護・福祉サービスを提供する

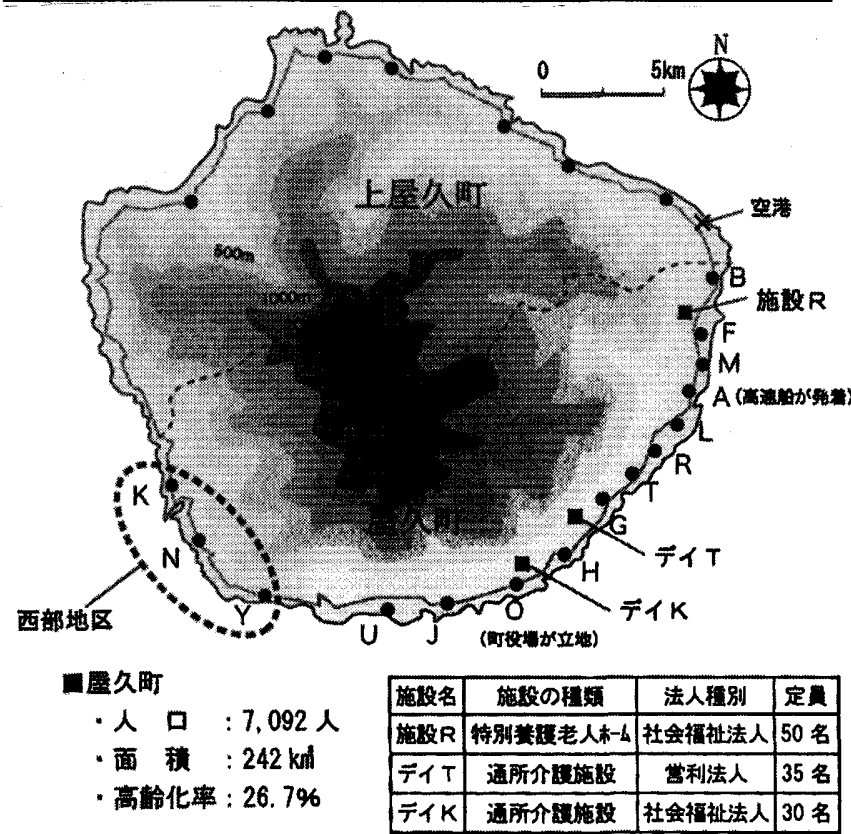

図 1 屋久町の概要と集落の立地状況

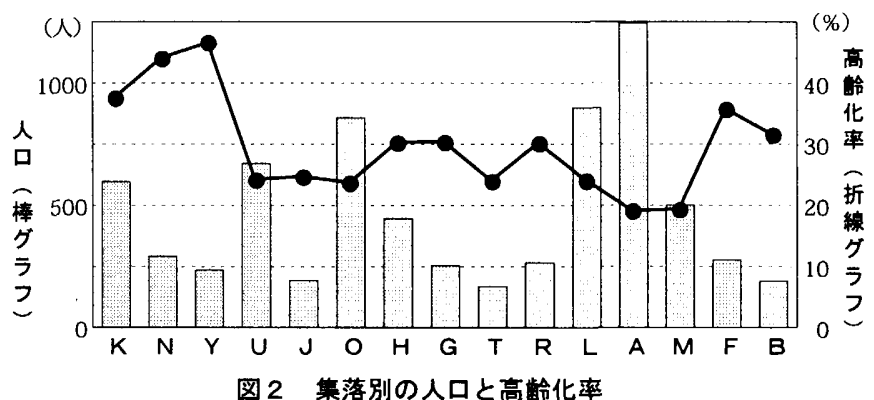

住民が地域における様々な問題に対してどのような創意工夫を行い、 高齢者施設の整備を実現していったのか、その経緯を明らかにすると 共に、施設の開設により地域に対してどのような変化をもたらした のかについて検証する。以上により、参加型福祉社会の構築に向けて、 今後增加していくことが予想される既存施設の改修や住民を主体と した活動に対して寄与しうる知見を得ることが本研究の目的である。

\section{3. 対象事例の概要と調查方法}

本研究の対象地域である鹿児島県屋久町は、屋久島の南側に位置 する (図 1)。島の中央は宮之浦岳を始めとする山間部と、世界遺産に も指定されている森林部で占められているため、大小合わせて 15 の 集落が 1.5〜 $5 \mathrm{~km}$ 置きに島の外周部に沿って立ち並んでいる。屋久 島と本土を結ぶ高速船が発着する $\mathrm{A}$ 集落や、役場がある $\mathrm{O}$ 集落がそ れぞれ町の東側・中央に位置しているのに対し、本研究の対象地域で ある「西部地区 $(\mathrm{K} \cdot \mathrm{N} \cdot \mathrm{Y} の 3$ 集落により構成)」は町の西側にあり 非常に奥まった場所に位置している。地区全体の人口は約 1,100 人、 高齢化率は約 $40 \%$ と著しく進行しているにも関わらず (図 2)、西部 地区では高齢者施設の整備がなされていなかったため、K集落を中心 とした西部地区住民により NPO 法人「サポート\&ケア屋久島」(以下

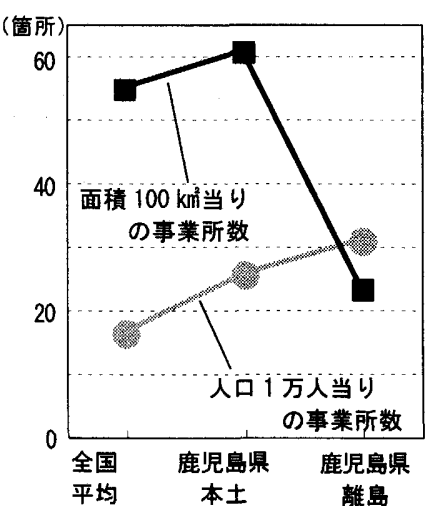

(a) 在宅サービス

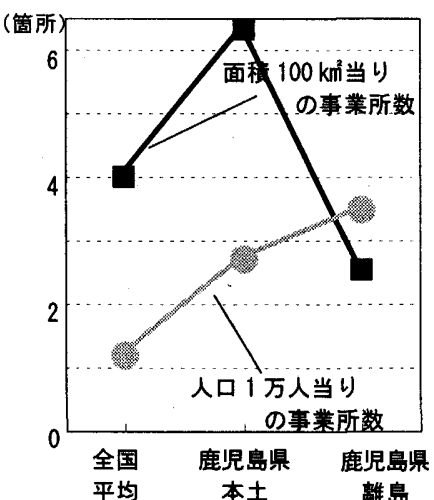

(b) 施設サービス
図 3 介護保険事業所数の比較

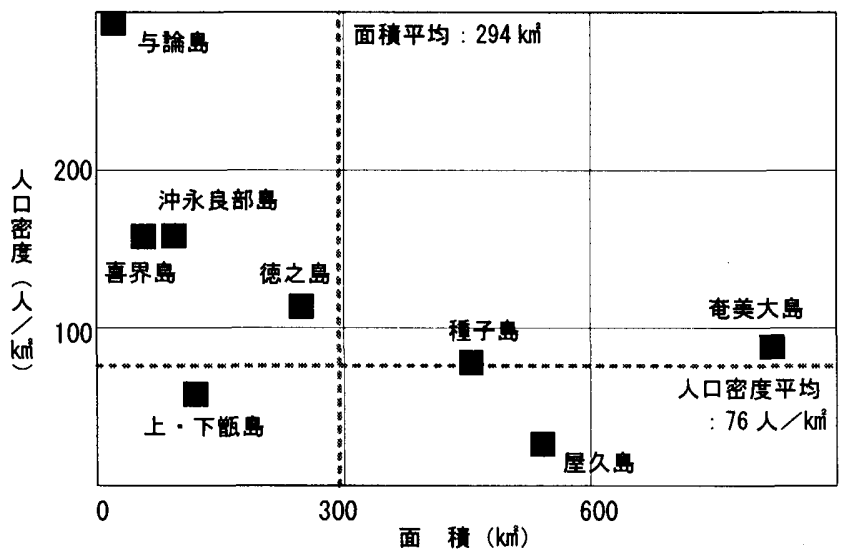

図 4 鹿児岛県内各離岛の面積と人口密度

NPO 屋久島と略) が 2003 年 12 月に設立された (表 1)。そして、廃校 となった校舎を自分達の手で改修することにより、2004 年 4 月から 通所介護事業所 $Y$ (以下ミニデイY と略) の運営が開始されている。

そこでまず離島や屋久町を取り巻く現状について把握するために、 文献を元に現状調査を行なった。次に 2004 年 3 月に予備調査とし て現地を訪れて学生数名と共に廃校校舎の改修工事にボランテイアと して参加した。その後 2004 年 6 月・9 月・ 11 月、2005 年 3 月・10 月に現地を訪れ、改修工事の経緯や NPO の活動内容についてのヒア リングを工事参加者・NPO 会員・ミニデイ職員に対して行った。

\section{4. 調查結果と考察}

\section{4-1. 対象地域を取り巻く状況}

対象地域を取り巻く状況について整理するために、はじめに離島 地域と全国平均との比較を行う。次に鹿児島県内の離島同士の比較 から屋久島の位置づけについて考察する（2003 年 4 月時点）。

まず全国と鹿児島県本土・鹿児島県離島の介護保険事業所数を人 口当りと面積当りで比較したもの ${ }^{\text {注 } 6}$ を図 3 に示す。図から離島の介 護保険事業所数は施設・在宅の両サービス共に全国平均と比べると、 人口当りの数值は大きいものの、面積当りの数值は逆に小さくなっ ている。つまり、離島では全国平均や本土と比べると、面積当りの介 護保険事業所が少なく、住民の住んでいる地域の近くに立地してい ない傾向にあると考えられる。

次に各島の特徵を比較するために鹿児島県の主な離島 8 島の人口 密度と面積を表したものを図 4 に示す。縦軸が各島の人口密度、横軸 が面積を表している。図中の点線に示すように、8 島の人口密度と面 
積の平均值で線を引くと、グラフ全体を大きく 4 つのエリアに分ける 事ができるが、屋久島は面積が大きくかつ人口密度が極端に低い、右 下のエリアに属する唯一の島である事が分かる。同じ離島でも面積が 小さくかつ人口密度が高い与論島や喜界島等と比較すると、サービス の供給という観点からは非常に不利な状況にある事が推察される。

そして、そこには地形的要因が大きく影響していると思われる。図 5 は、各島の等高線を $250 \mathrm{~m}$ 毎に地図上に表現したものであるが、他 の島では標高 $500 \mathrm{~m}$ 以上の箇所が全く見られないのに対して、屋久 島は中央に標高約 $2,000 \mathrm{~m}$ で九州最高峰の宮之浦岳が墕えているこ ともあり、土地の起伏が非常に激しく、集落や交通は島の外周部のみ に分散せざるをえない(図 1)。加えて、町内の通所・入所施設は 3 ケ 所のみで (表 1)、役場や船の発着場があり人口の多い集落付近へ立地 する傾向が見られる。そのため、役場や船の発着場から最も離れた 場所に位置する西部地区においては、立地条件がもたらす「距離」と いう問題が一層大きな制約になっていると考えられる注７。

\section{4-2. ミニデイY設立に至る過程}

工事参加者に対して行なったヒアリングの結果から、ミニデイY 設 立に至るまでの活動は、目的・組織・拠点という3つの観点から分 析すると、大きく 4 つの段階に整理する事ができた（図 6 )。以下、 各段階の内容について述べていく。

\section{4-2-1. 第 1 段階 集落自治組織の限界}

NPO としての活動は 2003 年に始まるが、一連の活動として捉え
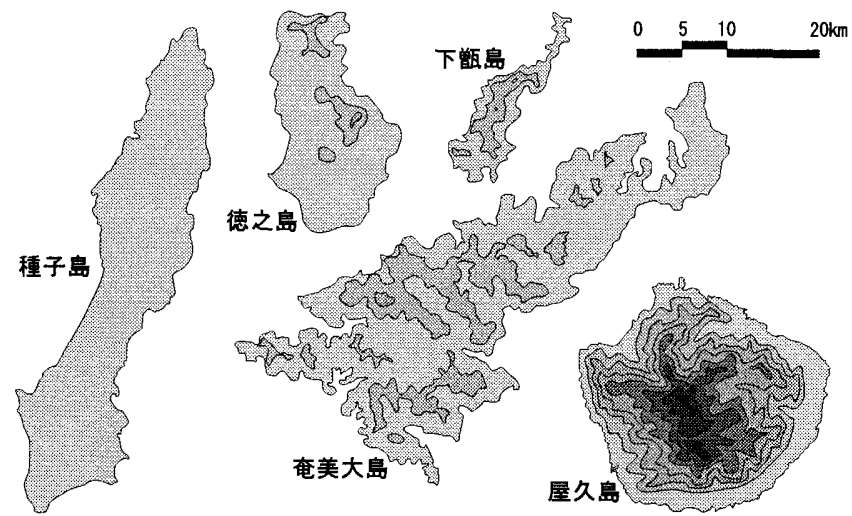

図 5 鹿児島県内各離島の地形（標高 $250 \mathrm{~m}$ 毎に等高線を作成）
ると、1999 年に始まった集落の自治組織である「村づくり委員会」に 端を発する。村づくり委員会は屋久町の「明るい農村づくり事業」と して組織化され、各集落が抱える問題を発見することから始まった。 その中で、高齢者介護の問題を日常生活の中で感じていた委員によ り、高齢者福祉対策として「福祉のまちづくり計画」が委員会に提案 され採択がなされたが、その計画は 4 年が経過しても実行には至ら なかった。その理由として、NPO 会員に対するヒアリングからは以下 の 3 点が挙げられた。まず第」の問題点は「構成員」である。自治組 織では集落全戸参加を原則に半強制的に参加が強いられていたため、 消極的な参加姿勢の人が多く、円滑な意思決定が困難となっていた。 第 2 の問題点は「財源」である。委員会で採択がなされたものの、財 源は集落全戸から集めたものであるため、住民全体に効果があるこ と以外に財源を使用することに対しては、実際に実行しようとする 段階で多くの反対意見が生じた。そのため、財源があるにも関わらず 使用することができないという不便さがあった。第 3 の問題点は「役 員の任期」である。役員の代表者である区長の任期は 2 年々比較的 短いものであったため、新しい計画を立ててもすぐに任期が終了し てしまい、計画を実行に結びつけていくのは困難な状況であった。

以上のことから、村づくり委員会という自治組織では、高齢者福 祉の対策は殆ど進展に至らなかった。

\section{4-2-2. 第 2 段階 新たな組織作り}

計画が実行に移せない事を確信した村づくり委員会の参加者 3 名 (表 2 ) を中心に、2003 年 4 月から新たな組織作りが始められた。在 宅高齢者の生活に対する問題意識が強く、活動の主旨に賛同した地域 住民 11 名がこの段階で参加する事になったにこの 11 名が後に NPO

\section{表 $2 N P 0$ 設立発起人の概要}

NFさん：50 代の医師で町立棒療所所長。屋久町出身で、9 年前に K 集落に診療所医師として赴任する。在宅での診療活動を行っ ていく中で地域の在宅高秢者が抱える問題を目の当たりに し、その解決に向けた活動の重要性を強く訴える。

SUさん：60 代の元役場職員。生まれも育ちもK集落で居住歷が非常 に長く、PTA や村づくり委員会等で集落の問題に関わる。 役場を退職後に始めた木材加工による家具製作が趣味。

Y I さん：30 代の薬剤師・薬局経営者。屋久町内の出身で、現在 K集 落内にて薬局を経営。30 代ながらも数年前に薬局を開設し た経験から、経営に関する知識を豊富に有する。

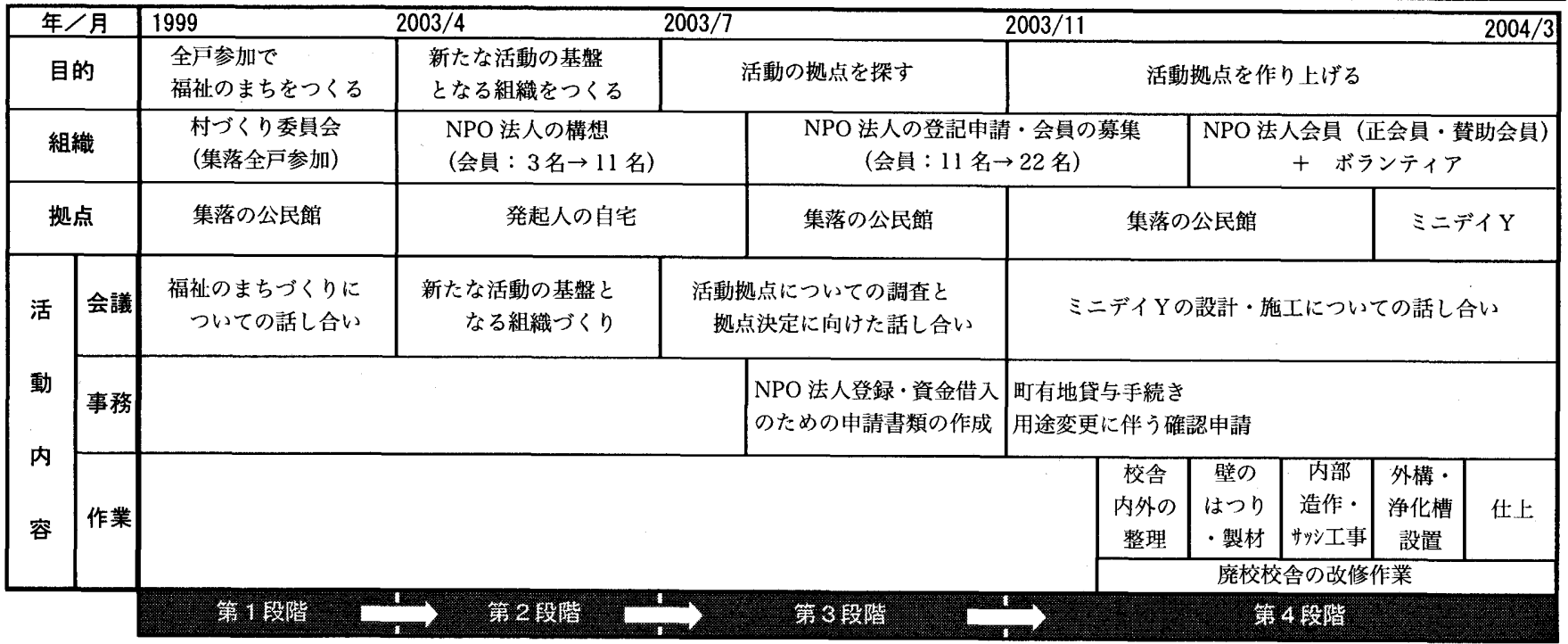

図 6 ミニディY設立に至る活動の過程 
法人の理事となる)。そして討議をした結果、以前の自治組織の問題 点に対する反省から、柔軟な対応が可能な組織としてNPO 法人が 選択された。まず構成員については、半強制的な参加ではなく有志 参加とし、少数精鋭による組織へと大きく変化した。そのため、意思 決定に関しても重要な決定事項以外は役員で決定でき、意志の決定 を迅速に行うことで機動性が大きく向上する事になった。また財源 については区費ではなく NPO が集める寄付・会費・事業収入を主 とする事で、大金では無いものの使い勝手のよい財源となった。そ して役員の任期に関しては、長期的な計画への対応が可能となるよ うに最長 6 年まで任期を継続できる事とした。

その後、数回の会議を経て、(1)西部地区では在宅で生活する重度の要 介護高秢者が多いこと、(2)家族による高㱓者介護が多いこと、(3)引き こもり高秢者の防止，(4)低収入の高柃者が多いため費用対効果を重視 する等の点を考慮し、早急に実施すべき対策として、重度の在宅高路 者を対象とした小規模な通所介護事業所を計画する事が決定された。

\section{4-2-3．第 3 段階 改修建物の選定}

第 3 段階において NPO 法人設立の手続きと並行して行われたの がミニデイYへ改修する建物の選定である。NPO 屋久島の財源は潤 沢ではなかったため、既存建物を改修する方法が模索された。候補 となった「元事務所」一般家屋」小学校の余裕教室」「廃校となった 中学校校舎 (以下、廃校校舎と略)」の 4 つの建物と、選定時に考虑 された問題との関係を表 3 に示す。改修する建物として最終的に廃 校校舎が選ばれる事になったが、各建物とその問題とを考慮ううと、

\section{表 3 候補建物と問題点の関係}

\begin{tabular}{|c|c|c|c|c|}
\hline & 元事務所 & 一般家屋 & 小学校・余裕教室 & 麾校校全 \\
\hline 浄化槽の設是 & $\Delta$ & $\Delta$ & 0 & $\Delta$ \\
\hline 車椅子への対応 & $\Delta$ & $x$ & $\Delta$ & $\Delta$ \\
\hline 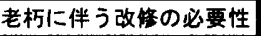 & $\Delta$ & $x$ & 0 & $x$ \\
\hline 所有権の問题 & $x$ & $x$ & $\bar{\Delta}$ & $\Delta$ \\
\hline 施設管理の問题 & 0 & 0 & $x$ & 0 \\
\hline 面種的余裕 & $x$ & 0 & 0 & 0 \\
\hline 補助金の有無 & $x$ & $x$ & $\mathrm{O}$ & $x$ \\
\hline
\end{tabular}

凡例 $O$ : 問題無し $\Delta:$ 若干問題あり $x$ : 問題あり

廃校校舎が改修に最も有利な条件にあった訳ではない。改修建物の 決定時に生じた問題の中でも特徴的であった 3 点について述べる。

まず第 1 に補助金の問題である。余裕教室の利用に関する補助金 は設けられていたが、廃校の利用に関する補助金は当時設けられて いなかった。同じ学校の校舎でありながら廃校か余裕教室かにより 補助金の支援が利用できないという実態があった。

第 2 に施設管理の問題である。余裕教室を利用する場合、校舎内で 通所介護を行う事になるが、今回の事例では運営時間帯の違いや高歯 者や介護職員が学校に出入りする等、異なる運営主体が同時に存在す ることで、施設管理に関するトラブルを学校側が大きく懸念した。そ のため補助金のメニューが設けられていた余裕教室の活用は、学校側 との折り合いがつかず、実現するまでには至らなかった。今回の事例 だけでなく、全国の余裕教室の活用状況を見ても学校施設以外への転 用の事例数は約 $3 \%$ に留まっており（図 7)、近年の学校内での様々な 事件の影響を考慮すると、余裕教室の学校施設以外への活用には未だ 多くの問題があると思われる。

第 3 は所有権の問題である。既存の建物を民間の所有者から借用 した場合、将来的に建築物が売却されたり解体されたりする可能性が あり、長期間の利用は保障されていない。しかしながら NPO 屋久島 では、ミニデイを長期的に運営していく事を計画していたため、元事 務所や一般家屋のように民間から建物を借りる事については、将来 的に建物を手放さざるをえない事態が発生しうることが慗念された。 これに対して廃校校舎の場合は、屋久町という自治体から校舎を借 りることになるため、建物の利用が長期に渡って保障されていた。

以上のような点が要因となり、改修する建物として廃校校舎が言 わば消去法的に選定されることになった。その後、行政側との間に

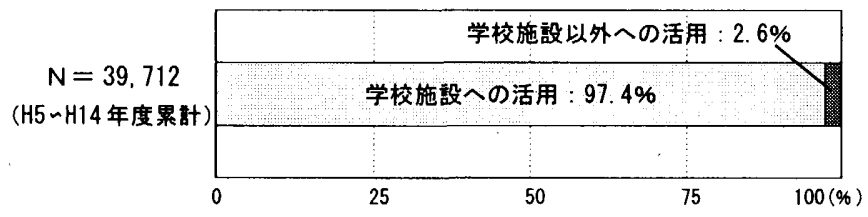

図7 全国小・中学校の余裕教室の活用状況（参考文献 14 より転用）

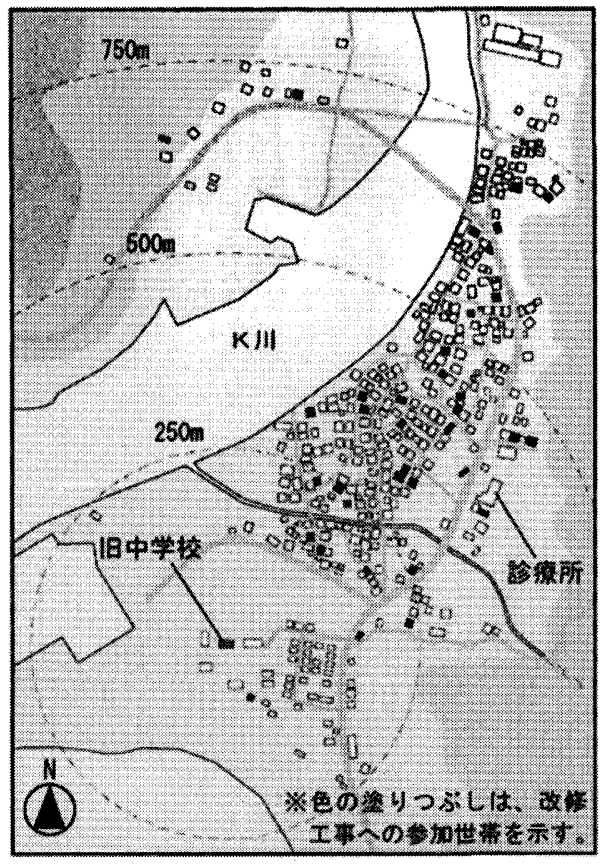

図 8 K集落図

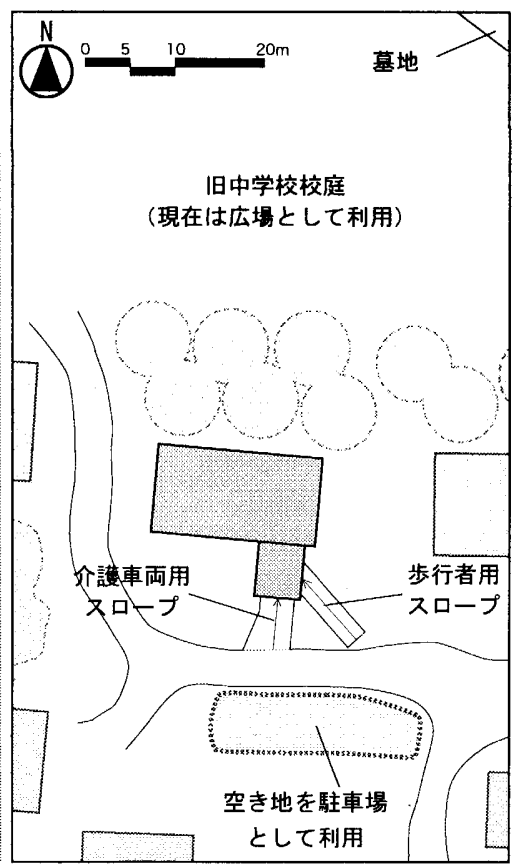

図 9 ミニデイY配置図

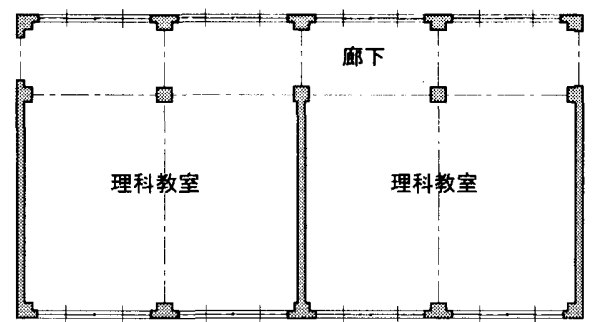

図 10 改修前平面図

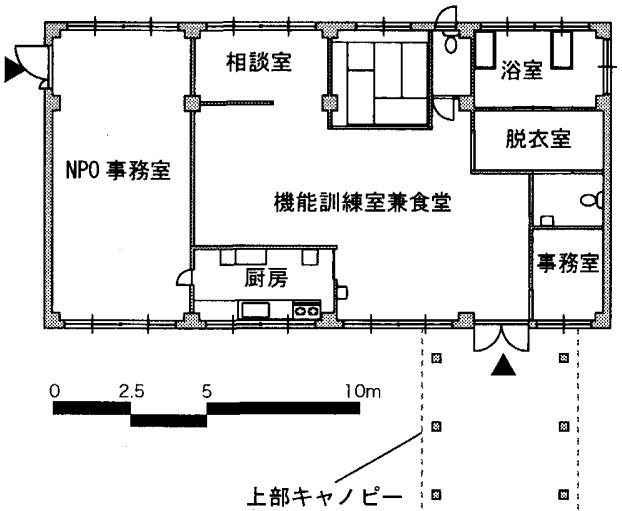

図 11 改修後平面図（2004 年 5 月 2005 年 2 月時） 
行われた手続きと担当窓口とを表 4 に示す。今回の事例では、一連 の活動の中心人物で NPO 法人の代表理事が、離島の町立診療所の 医師・所長を務めていたこともあり、町長へ直接交渉を行い、土地・ 建物を無償で利用することについて了承を得たため、行政との話し 合いは特に問題が生じることもなく、比較的スムーズに進行した。

\section{4-2-4. 第 4段階 廃校校舎の改修工事}

廃校となった中学校は、一般教室が設けられていた木造の校舎が 既に取り壊され、 RC 造の特別教室棟が数棟残るのみであった。廃校 後、既に 22 年が経過して木製サッシが壊れる等、建物はほぼゴミ㯰 き場と化しており大規模な改修を必要としていた（図 12・13)。図 9 に配置図、図 $10 \cdot 11$ に改修前後の平面図、表 5 に改修工事の具体 的な内容と費用の内訳を整理したものをそれぞれ示す。改修建物と して選定された理科教室棟は、 $\mathrm{R} \mathrm{C}$ 造の躯体が比較的しっかりして おり、雨漏りも無く屋根の防水工事が新たに必要ではなかった事か ら、改修工事は主に内装工事・サッシ工事・付帯設備工事を中心に進 められた注 8 。内装工事に関しては、高路者が日常生活を行う場であ るとの観点から、地元産の杉を用いて床・壁・扉等の造作が行われ た(図 15)。サッシ工事については、既存の木製サッシの腐朽が進行 しており、全ての開口部にアルミ製のサッシを新たに設ける必要が

表 4 改修工事の内容と費用の内訳

\begin{tabular}{|c|c|c|}
\hline 手続き & \multicolumn{2}{|c|}{ 担当㝕口 } \\
\hline $\begin{array}{c}\text { 町有地（建物） } \\
\text { 無償貸付契約 }\end{array}$ & 屋久町役場 & $\begin{array}{c}\text { 企画調整課 } \\
\text { 財産管理係 }\end{array}$ \\
\hline $\begin{array}{c}\text { 用途変更に伴う } \\
\text { 確認申請 }\end{array}$ & $\begin{array}{c}\text { 熊毛支庁 } \\
\text { 屋久島事務所 }\end{array}$ & 土木課 \\
\hline
\end{tabular}

あったため、サッシ工事には材料費だけで約 165 万円と多額の費用 が必要となった。また付帯設備工事については、高齢者施設という ことで浴室やトイレに加えて合併処理浄化槽の設置が新たに必要と なったため、給排水・衛生設備工事の費用も比較的大きな割合を占 めている。約 550 万円という非常に限られた予算の中で工事を遂行 するために、一連の改修工事では様々な試みがなされているが、限 られた予算と 4 ヶ月という短い期間の下で改修工事が可能となった 要因としては、人材·資源・技術の 3 点が挙げられる。

まず人材に関しては、予算の関係上、大工や建設会社等の専門業 者には依頼せず、近隣の地域住民や町内の技術者にボランテ仍としての 参加を募り、一連の改修工事が行われた。そのため、労務に掛かる費

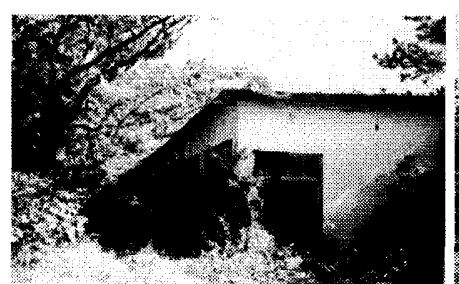
図 12 改修前外観

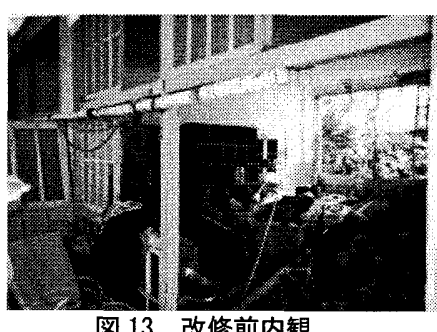

図 13 改修前内観

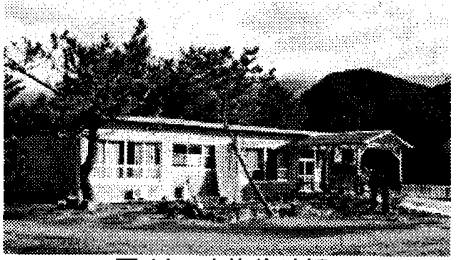

図 14 改修後外観

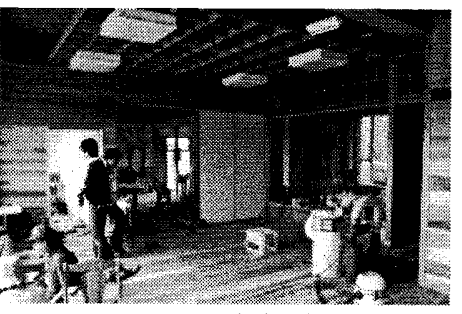

図 15 改修後内観

表 5 改修工事の内容と費用の内訳

\begin{tabular}{|c|c|c|c|c|c|}
\hline & 工事種別 & 作業分担 & 材料・器具の調達 & 労務費 & 材料費等 \\
\hline \multirow{3}{*}{$\begin{array}{l}\text { 建 } \\
\text { 物 } \\
\text { 事 }\end{array}$} & $\begin{array}{l}\text { 内装工事 } \\
\text { (壁・床工事) }\end{array}$ & $\begin{array}{l}\text { - 地域住民がボランケイアで工事を } \\
\text { 主に担当。 }\end{array}$ & $\begin{array}{l}\text { - 地元産の杉材を知合いの業者から購入。 } \\
\text { • プレかッ用の機械は地域住民が無償で提供。 } \\
\text { • 間仕切りやドア把手は州价。 }\end{array}$ & 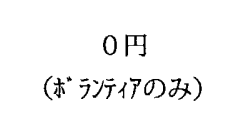 & $\begin{array}{c}\text { 約 } 74 \text { 万円（材木代） } \\
\text { 約 } 34 \text { 万円（釘・金具等代） }\end{array}$ \\
\hline & サッシ工事 & $\begin{array}{l}\text { ・町内出身の技術者がボラ゙ラ゙仍 } \\
\text { で工事を担当し、地域住民が } \\
\text { 支援を行った。 } \\
\end{array}$ & •サッシについては業者から新規で購入。 & $\begin{array}{c}0 円 \\
\text { (ボランデイのみ) }\end{array}$ & 約 165 万円（状シ本体代） \\
\hline & タイル工事 & $\begin{array}{l}\text { ·多仙職人である地域住民が } \\
\text { 無償ボランデイで担当。 }\end{array}$ & - タ价は職人から必要な分を新規で購入。 & $\begin{array}{c}0 円 ~ \\
\text { (ボランテテイアのみ) }\end{array}$ & 約 33 万円（タイル一式代） \\
\hline \multirow{2}{*}{$\begin{array}{l}\text { 付 } \\
\text { 带 } \\
\text { 設 } \\
\text { 備 } \\
\text { 軍 }\end{array}$} & $\begin{array}{c}\text { 給排水・衛生 } \\
\text { 設備工事 }\end{array}$ & 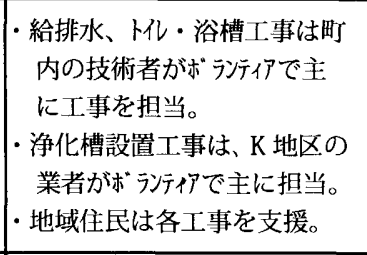 & 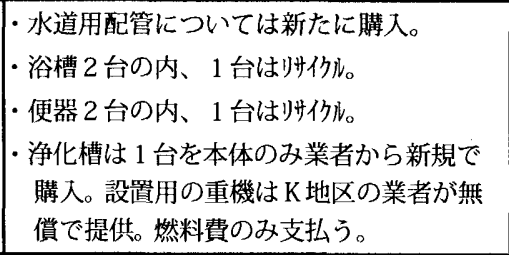 & $\begin{array}{c}0 \text { 円 } \\
\text { (ボランティイのみ) }\end{array}$ & $\begin{array}{c}\text { 約 } 24 \text { 万円（配管用品代） } \\
\text { 約 } 53 \text { 万円（衛生機器一式代） } \\
\text { 約 } 53 \text { 万円（浄化槽本体代） } \\
\text { 約 } 10 \text { 万円（重機燃料代） } \\
\text { 約 } 9 \text { 万円（検査手数料） }\end{array}$ \\
\hline & $\begin{array}{l}\text { 電気·空調 } \\
\text { 設備工事 }\end{array}$ & 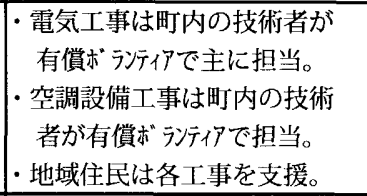 & $\begin{array}{l}\text { ·照明器具は州仍品を利用。 } \\
\text { ·空調設備は業務用エアコンを归仍ルで利用。 } \\
\text { ·電気工事用配線部品は新規で購入。 }\end{array}$ & $\begin{array}{c}\text { 約 } 13 \text { 万円 } \\
\text { (電気工事労務費) } \\
\text { 約 } 15 \text { 万円 } \\
\text { (空調設備労務費) }\end{array}$ & 約 2 万円（配線部品代） \\
\hline $\begin{array}{l}\text { 外 } \\
\text { 構 } \\
\text { I } \\
\text { 事 }\end{array}$ & 外構工事 & \begin{tabular}{|l} 
• 専門的な内容の工事は $\mathrm{K}$ 地区 \\
内の業者に依頼。その他に \\
ついては地域住民が担当。 \\
\end{tabular} & $\begin{array}{l}\cdot \text { ・コンクリートは業者から新たに購入。 } \\
\cdot \text { 外構工事は主に前庭の整備と吅-プの設置。 }\end{array}$ & $\begin{array}{c}\text { 約 } 9 \text { 万円 } \\
\text { (外構工事労務費) }\end{array}$ & 約 20 万円（生コン代） \\
\hline $\begin{array}{l}\text { そ } \\
\text { 他 }\end{array}$ & - & $\begin{array}{l}\text { · K地区内の元大工職人が } \\
\text { 現場責任者を担当。 }\end{array}$ & \begin{tabular}{|l|} 
その他、家具やガスレンジ、欴房機器、 \\
台所用品、事務室備品など、多くのもの \\
を無償提供もしくはリサイクルしている。
\end{tabular} & $\begin{array}{c}\text { 約 } 30 \text { 万円 } \\
\text { (現場責任者労務費) }\end{array}$ & 約 5 万円（消防器具代） \\
\hline \multicolumn{4}{|c|}{ 費用小計 } & 約 67 万円 & 約 482 万円 \\
\hline \multicolumn{4}{|c|}{ 費用合計 } & \multicolumn{2}{|c|}{ 約 550 万円 } \\
\hline
\end{tabular}


用を大きく削減することが可能となり、建築工事費用全体に占める 労務費の割合は約 10\%強と非常に低い值となっている。改修工事 には 30〜 60 代を中心に幅広い年代の方々が参加しており、その人 数は 55 名に達する (図 16)。参加者の 8 割以上は西部地区に住む地 域住民の方々であるが、特に徒歩圈内に住んでいるK集落からの参 加者は 36 人と全体の約 6 割を占めており、旧中学校ということで 敷地が集落内の通いやすい場所に立地していたことも少なからず影 響していたと思われる（図 8)。また改修工事の参加者の中には、約 60 年前に当該校舎の建設工事を手伝ったことがあるという方も数 人おられた。壁や床等の内装工事は主に地域住民がボランテ仍で作業 を担っているが、州江事や付带設備工事等は町内の技術者や町出身 の技術者が术ランテ仍もしくは有償术ランテ仍で工事に参加しており、地 域住民では作業が難しい工事については技術者との間で役割分担が 行われている様子が窺える (表 5 )。加えて、一般家庭には無い大型 の機械や大型特殊自動車については、N集落の土木会社社長が NPO の理事を務めている事から無償で重機が提供される等しており、地 域住民のマンパワーに町内の技術者や企業の専門技術が組み合わさ れる事で、専門的な工事の遂行が可能になったと考えられる。

資源については、廃屋や空家から使用されなくなった備品や建具 を譲り受けたり買い取ったりするなど、より多くの物品を改修工事 に再利用する事で費用の削隇が行われた。具体的に再利用されたも のとしては、手摺や間仕切・ドアの把手といった建具類だけでなく、 照明器具やエアコン・浴槽・便器といった設備機器なども挙げられ る（表 5 )。そのため改修の際には、再利用した建具や物品に合わ せて開口部の幅や天井高の寸法が決定されるなど、物品の再利用を 見据兊た計画が行われていた。

また技術に関しては、改修作業に参加した人の殆どは大下.仕事を職 業としている方ではなかったが、住宅新築の際には近隣住民が工事を 手伝うという地域の風習から、作業の中心となった 50 ～60歳代の 参加者の多くが基本的な大工技術を有していた。また、改修作業に用 いられた大工道具や電気工具の殆どは参加者の自宅から持ち寄られ た物であった。ここには、毎年の台風対策や被害の修繥をするために 簡単な工作道具が各家庭に揃っており、使い慣れている方も非常に多 かった、という地域の特性も大きな要因となっていたと考えられる。

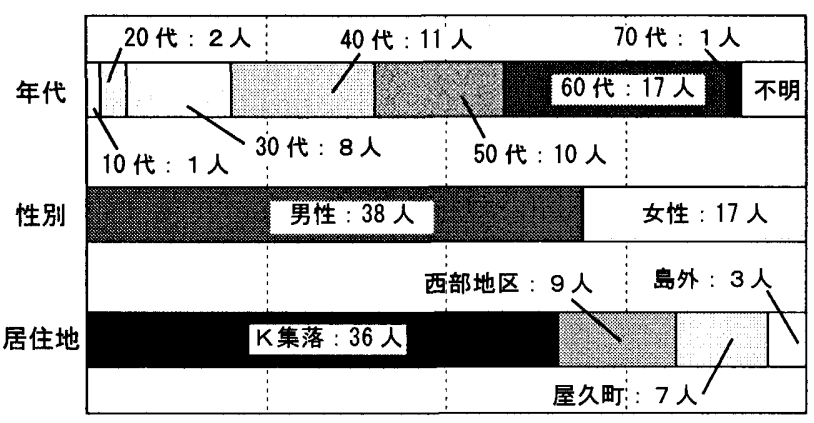

図 16 工事参加者属性

表 6 ミニデイYの概要

\begin{tabular}{|c|c|}
\hline 開設 & 2004 年 4 月 \\
\hline 定員 & 通所介護 10 名 /日（拡張により 2005 年 4 月から 15 名 / 日） \\
\hline 職員数 & 9名（介護職員 7 名 + 欴房職員 2名） \\
\hline 営業日 & 月〜土曜日までの週 6 日 \\
\hline 延床面積 & $132 \mathrm{~m}^{2}$ (拡張後は $\left.177.5 \mathrm{~m}^{2}\right)$ \\
\hline 送迎 & 西部地区内については福祉車両により対応 \\
\hline
\end{tabular}

\section{$4-3$. ミニデイY開設後の実態}

4-3-1. ミニデイの利用傾向

高柃者施設が地域の中に設けられていなかった西部地区でミニデ イYが運営を開始したことに伴って（表 6 )、利用者の利用状況はど のようなものであったのか、開設後 1 年間の変化について確認する。

まずミニデイYの全利用者数と一日平均利用者数の変化を図 17 に示す。開設当初は全利用者数が 9 人、一日平均利用者数も定員 10 名に対して 2.8 人と共に少なかったものの、開設後半年が経過して からの全利用者数は 16 人、一日平均利用者数も約 7 人と徐々に増加 しつつある。このような利用者数の増加に伴って 2005 年 3 月には 拡張工事を行い注 9 、同年 4 月からは定員を 15 名に増加するまでに 至っている。また利用者の $90 \%$ 以上は西部地区内に居住する高齢 者であり、小規模ながらも地域に密着した形で運営がなされている。

次に通所介護利用者の要介護度別割合について、全国平均と屋久 町の事例の結果を図 18 に示す注 10 。図を見ると全国平均・町内のデイ 施設 $\mathrm{K} \cdot \mathrm{T}$ においては、要支援・要介護 1 の利用者が全体の $50 \%$ 以 上を占めており、特にデイTにおいては $65 \%$ を上回る等、全体的に 軽度の要介護高柃者で大きなウエイトが占められている。これに対し てミニデイYでは、要支援・要介護 1 の利用者が占める割合は全体の 約 $1 / 3$ に留まっており、要介護度 3 以上の中〜重度の要介護高秢者 の割合が全国平均及びデイ施設 $\mathrm{K} \cdot \mathrm{T}$ と比較すると非常に高い事が わかる。特にデイ K・Tの両事業所においては、要介護 5 の高龄者の 利用は全く見られていない。小規模な事業所であるミニデイYにおい てこのような重度高柃者への対応が可能となっている要因としては、 NPO 屋久島の代表理事でもある診療所の医師との緊密な連携がなさ れている事が非常に大きいと考えられる。ミニデイYから診療所まで

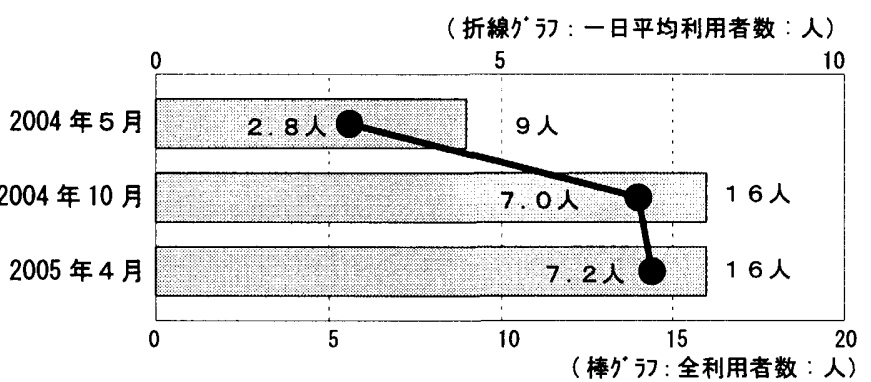

图 17 ミニデイY 全利用者数と一日平均利用者数の变化
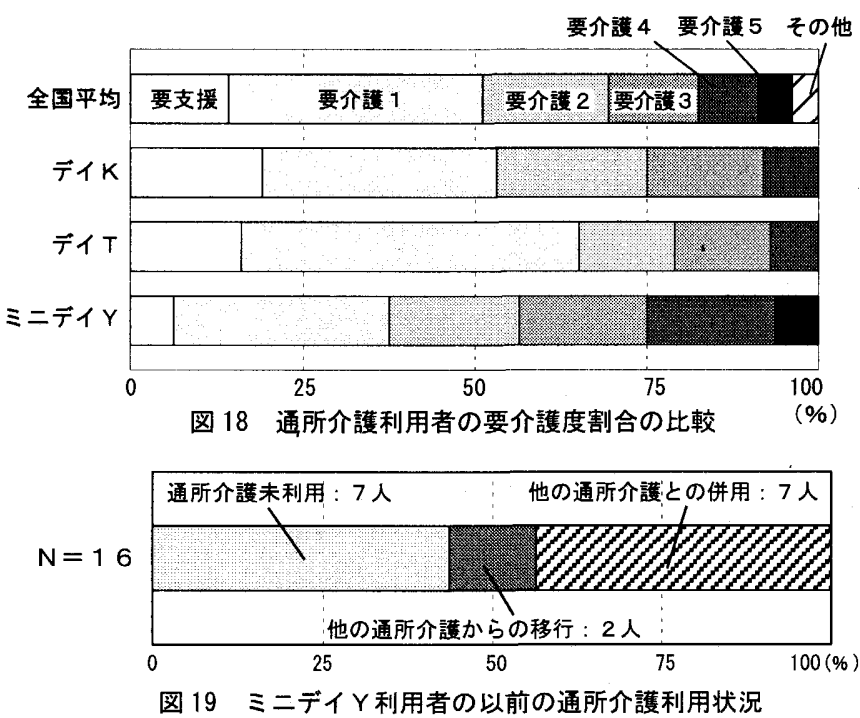
は約 $400 \mathrm{~m}$ と非常に近く、診療所医師による訪問が安否確認 を兼ねる形でほぼ毎日行われている。

最後に 2005 年 4 月時点でのミニデイY利用者 16 人につ いて、以前の通所介護サービスの利用状況を図 19 に示す。 図を見ると、利用者 16 人の内、約半数が以前は通所介護を 利用していなかった人となっており、施設が自宅の近くに無 かったために通所サービスを利用したくても利用できなかっ た高齢者も少なくないと思われる。また残りの半数は以前も 他の通所介護を利用していた人であるが、西部地区内にミニ デイYができたことで、現在ではミニデイYだけの利用へと 移行している高秢者も数人見られる。

\section{$4-3-2$. ミニデイ利用者の生活の変化}

次に、ミニデイYの利用者と職員に行なったヒアリング調査 から、その生活が利用前後でどのように変化したのかについ て考察する。大きな効果が見られた利用者 3 人について、利 用開始前後の生活と日常の行動範囲を図 $20 \sim 22$ に示す。

図 20 は一人暮らしをしている 90 代の女性の事例である。 多少の介助が必要であるが生活面はほぼ自立しており、デイ Kを利用したり数人の友人に助けてもらったりしながら在宅 での生活を続けてきた。しかしながら持病の腰痛が悪化した ことで、長時間の車の乗車を必要とするデイ Kの利用や自宅 での入浴は難しい状況となった。一方で本人は「自宅で暮ら したい」他の人と交流したい」という希望を強く持っていた ことから、近所に開設したミニデイYを利用しながら在宅での 生活を続けることとなった。腰の状態はその後も良好ではな いものの、近距離にあるミニデイYを利用する事で地域の高㠿 者と交流する機会を保ちながら、在宅での生活が可能となっ ている。Y Kさんの事例以外でも、「長時間の車の乗車は乗り 物酔いしてしまう」職員など周りの人は知らない人ばかり といった回答も得られており、自宅から通所施設までの「距離」 が高㱓者にもたらす弊害は少なくないと考えられる。

図 21 は、中程度の認知症を患っている80 代の男性の事 例である。K集落内に夫婦で生活しており、妻の介助を受け ながら在宅での生活を継続している。2〜3 年前から認知症 状が目立つようになり、外出しては集落内を徘䧃する事が多 くなったため、目を離すことができない妻の介護負担は非常 に重い状況であった。近所には介護保険事業所が全く無かっ たため以前は介護保険サービスを全く利用していなかった が、ミニデイ Yが近所に開設したこともあり、Y Tさんは日 中の時間帯にミニデイYを利用することとなった。ミニデイ 利用後も $\mathrm{Y} T$ T んの集落内での俳徊は見られるものの、ミニ デイを利用することで介護者である妻の負担が非常に軽減さ れており、現在も在宅での生活が継続されている。

図 22 は集落外れに住む 80 代の高齢夫婦の事例である。肺 気腫を患っているため、酸素療法を必要とする夫の介護を身 障者 1 級の妻が行っている。夫は常に酸素療法を必要とする ため、町内のデイサービスでは医療面での対応が困難なことか ら、これまでッパーや配食少ーピスを利用しながら在宅での生活を 行ってきた。妻は夫を残して外出することができず、夫婦共に

\begin{tabular}{|c|c|}
\hline 品 & Y Kさん（女性） \\
\hline 概 & $\begin{array}{l}91 \text { 才、要介護度 } 1 。 K \text { 集落に } \\
\text { て独居生活。多少の介介助は必要 } \\
\text { だが生活面はほぼ自立。 }\end{array}$ \\
\hline & 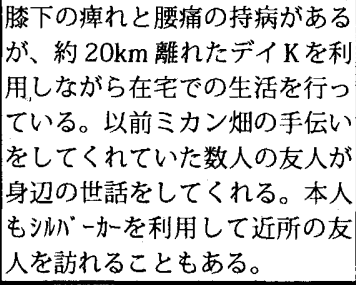 \\
\hline & $\begin{array}{l}\text { 持病の腰痛が悪化したため、長 } \\
\text { 時の間の車の移動が困難となる。 } \\
\text { しかし「自宅で暮らしたい」「他 } \\
\text { の人と交流したい」という本人 } \\
\text { の希望により、距離の離れたデ } \\
\text { イKから近距離にあるミニディ } \\
\text { Yを利用するようになり、在宅 } \\
\text { での生活を継続している。 }\end{array}$ \\
\hline
\end{tabular}

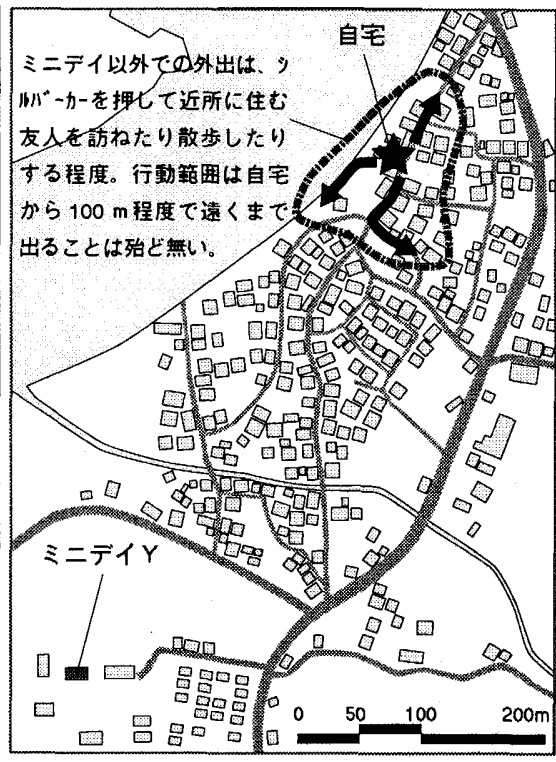

図 $20 Y K$ Y さんのミニデイY 利用前後の生活内容と行動範囲

\begin{tabular}{|c|c|}
\hline & Y Tさん（男性） \\
\hline & $\begin{array}{l}84 \text { 才、要介護度 } 1 \text { 。K集落に } \\
\text { て夫婦で生活。中程度の認知将 } \\
\text { で集落内を俳䧃する事が多い。 }\end{array}$ \\
\hline & 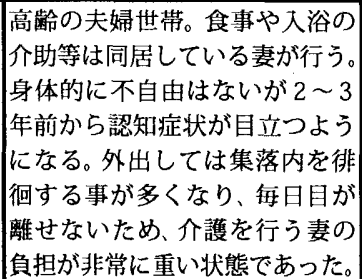 \\
\hline & 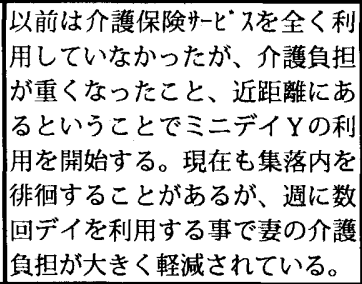 \\
\hline
\end{tabular}

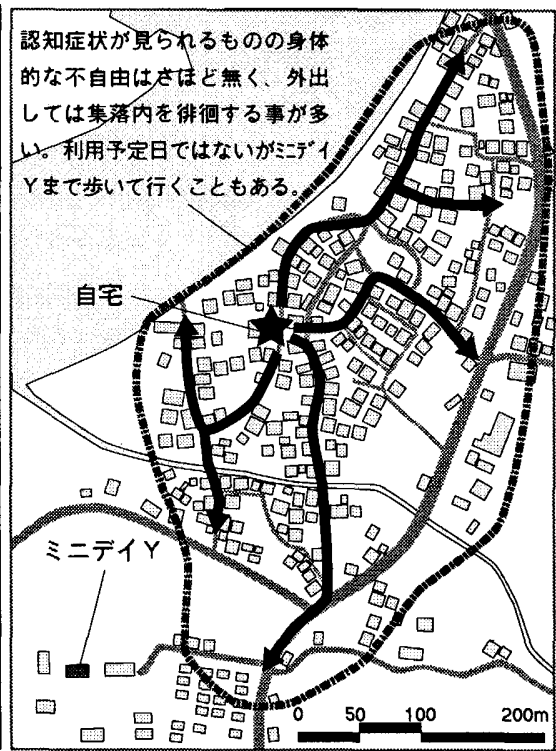

図 $21 Y T$ さ

\begin{tabular}{|c|c|}
\hline & 夫婦 \\
\hline & $\begin{array}{l}\text { 必要な夫の介 } \\
\text { の妻が行う。 }\end{array}$ \\
\hline & 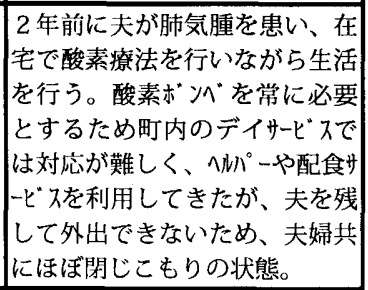 \\
\hline & $\begin{array}{l}\text { 診療所にも近く、医師が頻縏に } \\
\text { 足を運ぶということで、夫婦で } \\
\text { ミニデイYの利用を開始。妻の } \\
\text { 介護負担が軽減されただけでな } \\
\text { く、閉じこもりの生活から解放 } \\
\text { され、夫婦共に希望していた多 }\end{array}$ \\
\hline
\end{tabular}

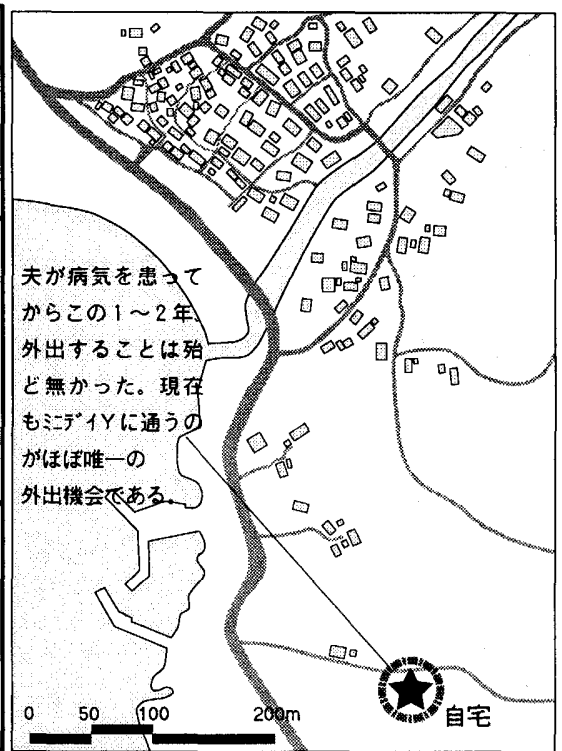

図 22 I Y・ISさんのミニデイY利用前後の生活内容と行動範囲 
殆ど自宅内に閉じ籠もつた生活であった。ミニデイYで診療所医師が 頻繁に足を運んでおり、酸素療法への対応も可能であったことから、 夫婦共にミニデイの利用を開始することとなる。ミニデイを利用する ようになった事で、日中は夫の面倒を見る必要が無くなり妻の介護 負担が軽減されたことに加えて、これまで殆ど自宅内に閉じ籠もつ たままの生活から解放され、夫婦共に希望していた他者との交流が 可能となる等、在宅における生活の質に大幅な向上が見られている。

\section{5. まとめ}

本研究では、過疎・離島地域において住民が主体となって廃校か ら通所介護施設への転用が行われた事例を対象として、転用に至る までの過程と、施設開設後の利用状況について調査を行った。その 結果は以下の通りである。

1) 高齢者が自宅での居住継続を希望する場合、自宅から事業所ま での「距離」は在宅サービスを利用する上で大きな障害になると考 えられるが、文献調查の結果から、離島地域の介護保険事業所数 は全国平均と比べると人口当たりの数では多いものの、逆に面積 当たりの数は少ないことが明らかになった。面積当たりの数が少 ないということは、個々の事業所がカバーする範囲が広くなると 共に自宅から事業所までの「距離」が離れる傾向にあることを示 唆しており、利用者の視点からみた高柃者施設の立地条件は離島 地域に共通する問題であると考えられる。

2 ）ヒアリング調査の結果から、廃校校舎の転用により通所介護施設 が開設されるまでの活動を 4 つの段階に分類する事で、地域住民 が主体となって実現された活動の全体像が明らかになった。特に、 限られた予算の中での改修工事が可能となった背景には、地域住 民や技術者・企業がボランティアとして参加する事で労務に掛かる 費用を大幅に抑える事が可能になったこと、地域住民のマンパワー に技術者と企業の専門技術が組み合わされる事で専門的な工事の 遂行が可能になったこと、が大きな要因となっていることを示し、 地域住民による「共」の取組みの成功要因について指摘した。

3 ）通所介護施設利用者の生活内容に関するヒアリング調査の結果 から、住み慣れた地域の近くに通所介護事業所が存在することで、 高齢者自身、又はその介護者の生活に及ぼす効果の一端が明らか になった。対象地域のように小規模な集落が分散している地域に おいては、小規模な施設を分散して地域全体に配置していくこと で在宅高齢者の生活に大きな効果が得られると考えられる。

4) NPO 屋久島の活動はミニデイYが終着点ではなく、あくまでも 出発点である。地域住民を中心とした活動が今後も続いていく中 で、在宅高跘者が求めるニーズにどう対応していくのか、高㱓化 が著しく進行する離島の集落においてはどのような可能性と限界 があるのか、といったことについても追跡調查していくことを 今後の課題としたい。

\section{謝辞}

本研究を行う上で、屋久町診療所所長藤村憲治氏、上山舜一郎氏をはじめ とするNPO 法人サポート\&ケア屋久島の皆様にはヒアリング調查や資料収 集に多大なる御協力を頂きました。また調査データの集計においては、当時、 卒論生の藤本健君の協力を得ました。末筆ながら感謝の意を表します。

尚、本研究は平成 16-17 年度文部科学省科学研究費「若手研究B 課題番 号 16760495 研究代表者 鉿木健二」の助成によるものである。
注

注 1) 文献 1では、生まれ育った島を離れて島外の福祉施設に入居している 高齢者に対して、故郷の島への一時帰省を支援する沖䋖県竹富町「いきい きふるさと訪問事業」の取り組みが報告されている。

注 2）文献 4 による。

注 3 ）文献 5 ・6による。

注 4 ) 文献 $7 \cdot 8 \cdot 9 \cdot 10$ による。

- 注 5 ）文献 $11 \cdot 12$ による。

注 6）データは、NPO 屋久島の活動が動き始めた時期である 2003 年 4 月時 点のものであり、文献 13 や独立行政法人福祉医療機構による wam net の ホームページ（http://www.wam.go.jp/）を元に作成。

注 7 ）文献 14 に括いては、在宅・施設サービスを利用している都市部の要介 護高制者の現状についての考察がなされている。これによると、都市部に おける自宅から利用施設までの距離は、通所介護では $2 \mathrm{~km}$ 未満が $64 \% 、 2$ $\mathrm{km}$ 以上 $20 \mathrm{~km}$ 未満が $36 \%$ と報告されており、半数以上が $2 \mathrm{~km}$ 末満の生活圈 内で利用がなされている。しかしながら K集落を例に挙げた場合、通所介 護・施設介護の事業所は $2 \mathrm{~km}$ 以内はおろか、20 km以内ですら見られない。 注 8 ）尚、今回の廃校施設の利用に当たっては、建物の耐震診断についての 考慮は行なっていない。

注 9 ) 2005 年 3 月の拡張工事により、現在では図 11 の NPO 事務室の部分 までがミニデイのスペースとして拡張されている。

注 10）全国平均の数值については文献 18 より 2004 年 9 月のデー夕を、 ミニデイYについては 2005 年 4 月のデータを、他の 2 施設の数值につい てはヒアリング調査から得た 2004 年 8 月のデータを用いている。

\section{考文献}

1) 吉原昌也、鈴木健二他 2 名：住民主体による廃校から高龄者施設への 転用プロセスに関する研究 その1 地域の概要と離島の現状について 日本建築学会大会学術講演梗概集、E-1、pp377-378、2005 年

2 ) 御手洗政和、鉿木健二他 2 名：住民主体による廃校から高龄者施設への 転用プロセスに関する研究 その 2 改修に至る転用プロセスについて 日本建築学会大会学術講演梗概集、E-1、pp379-380、2005 年

3 ）地域からの発想・沖縄県竹富町、月刊厚生労働、pp31-37、2003 年 7 月

4 ）内閣府：平成 16 年版国民生活白書、2004 年

5 ) 卯月盛夫:住民の主体的なまちづくり活動を支援する「まちづくりセンター」 に関する研究、日本建築学会計画系論文集、第 470 号、ppl61-172、 1995 年 4 月

6) 田口太郎、他 1 名：まちづくり活動主体の自立プロセスと自治体シンク タンクの役割に関する研究、日本建築学会計画系論文集、第 587 号、 pp 135-141、2005 年 1月

7 ）森永良丙、他 2 名:「状洗づくり」の視点からみた参加型集住体計画の研究 日本建築学会計画系論文集、第 478 号、pp69-78、1995 年 12 月

8 ）森永良丙、他 2 名：共用・私的空間の境界における住み手と環境の相互 浸透関係の考察、日本建築学会計画系諭文集、第 487 号、pp69-77、 1996 年 9 月

9）村田義郎、他 1 名:公営住宅建替計画策定における住民参加とソーシャル. サポートに関する考察、日本建築学会計画系論文集、第 523 号、 pp171-178、1999 年 9 月

10）白石昌之、他 2 名：住環境整備事業からまちづくり活動への漸進的展開 にみるワークショップの課題、日本建築学会計画系論文集、第 536 号、 pp 199-206、2000年10月

11）浜崎裕子、他 1 名：高齢者施設の脱施設化計画への住民参画プロセスの 研究、日本建築学会計画系論文集、第 547 号、ppl11-118、2001 年 $9^{3}$ 月

12）浜猗裕子、他 1 名:生活と空間のカップリングとしての「場所」の設計の考察、 日本建築学会計画系論文集、第 560 号、pp 127-134、2002 年 10 月

13）鹿肾島県社会福祉協議会：保健・福祉施設一覧、2003 年 8 月

14）絹川麻里、他 2 名: 要介護高龄者の施設入居前の生活䒠態からみた在宅 生活の意義と限界、日本建築学会尌画系論文集、第 582 号、pp 17-23、 2004 年 8 月

15）文部科学省 : 廃校施設の実態及び有效活用等調查研究報告書、2003 年

16）文部科学省 H P : 余裕教室の活用について H Pアドレス (http://www.mext.go.jp/a_menu/shotou/zyosei/yoyuu.htm)

17）鹿児島県屋久町: 屋久町老人保健福祉計画・介護保険事業計画、2003 年 3 月

18）厚生労働省：平成 16 年介護サービス施設・事業所調查結果速報 HP アト`レ (http://www.mhlw.go.jp/toukei/saikin/hw/kaigo/kaigo04/gaiyo.html) 